Prepared for the Conference on Entrepreneurship and Economic Growth Max-Planck Institute and the Kauffman Foundation

Ringberg Castle, Tegernsee (Munich), May 8-9, 2006.

\title{
Toward a Model of Innovation and Performance Along the Lines of Knight, Keynes, Hayek and M. Polanyi
}

\author{
Edmund S. Phelps*
}

Capitalist systems are private-ownership systems distinguished by openness to implementing new commercial ideas - ideas for new products and methods - and by decentralized, pluralistic mechanisms for selecting the ideas to finance and providing the needed capital and incentives. The economic system in the U.S. is broadly of that type. The sort of system in continental western Europe is so constrained by institutions and regulations intended for the protection of stakeholders and "social partners" that it goes by other names - corporatism or the social market economy. China's system must be called "state capitalism" because its financial sector is state-run. How these three systems affect innovation and economic performance is a topic of lively discussion today.

To many proponents - Schumpeter, for example - and critics - Marx, for one - capitalism's strength is its dynamism - the readiness and adeptness with which it moves forward. No doubt this dynamism derives in part from the creativity of business people and the acuity of the financiers judging which entrepreneurial ideas to back. ${ }^{1}$ Yet our understanding of the mechanisms and economic institutions involved, and why capitalism's dynamism is apparently hard to match, has not advanced far since the seminal insights of the early modern theorists of capitalism - notably Knight, Hayek and M. Polanyi.

I first review their legacy, which is not widely known. I then sketch elements of a model building on their insights, examine some of its implications and discuss recent and postwar experience from its perspective.

\section{The Beginnings of Capitalism Theory}

A student relying on secondary sources might surmise that the theory of capitalism's dynamism originates in the classical case for competitive markets - a case first made by Adam Smith two centuries ago. This classical thesis was that the presence of many buyers and sellers competing with one another in the

\footnotetext{
* McVickar Professor of Political Economy and Director, Center on Capitalism and Society, Earth Institute, Columbia University. Max Amarante and Hian Teck Hoon have collaborated with me on aspects of this paper.

${ }^{1}$ Capitalism also has a reputation for instability, thus job insecurity, and for incomplete inclusion of the disadvantaged. These issues are outside the scope of the present paper however. (I would comment only that the capitalist economies have done better at job creation and inclusion than the corporatist economies have.)
} 
marketplace caused wasteful resource allocations to be weeded out "as if by an invisible hand." 2 Under equilibrium conditions, efficiency in production prevailed. (One person's choice could be expanded only at the expense of another's.) This valuable feature of unimpeded markets, even if not fully realized, could not be matched by a government bureau: there were just too many goods and factors for a central planner to cope with. The point was made against communism by both "market socialism" theorists and capitalism theorist in the Interwar years of the $20^{\text {th }}$ century. ${ }^{3}$

Going farther, Ludwig von Mises, another of the early moderns (and also a champion of capitalism), argued in the early 1920s that market socialism, a new system then beginning to be envisioned, would also fail to match the efficiency of market economies under private ownership. If managers did not receive the profit and bear the risks of their decisions, the resource allocations of socialist competition would be highly inefficient - an argument that effectively founded property-rights theory. ${ }^{4}$

However, Mises's theoretical argument that competition with private ownership delivered greater economic efficiency than state-run competition would did not imply that the former competition also delivered greater dynamism - or indeed any dynamism. It was left open whether competition among firms suffices to generate dynamism without private owners. And whether private ownership suffices for dynamism without competition.

It might be thought that the theory of capitalism's dynamism originates in the pioneering work on economic advances by the German School led by Arthur Spiethoff and Gustav Cassel in the first decade of the $20^{\text {th }}$ century. Thanks to them, economic advances became a leading object of research for decades to come. Their work linked innovations to forces taken to be exogenous to the market economy, such as technological breakthroughs and the opening up of overseas markets and materials. ${ }^{5}$ A new discovery created new outlets for investment. The investments made "express the zeal of employers to profit by meeting the increased demand of the community for fixed capital." This provided a useful view of some historically

\footnotetext{
2 This section expands and revises material I wrote with contributions and suggestions from Roman Frydman and Andrzej Rapaczynski in 2001 for the website of the Center on Capitalism and Society.

3 Oskar Lange famously attributed the proposition to Mises. So had Hayek a little earlier. Mises, thinking of his book as a more original and profound criticism of market socialism, did not welcome the credit.

4 Ludwig von Mises, Die Gemeinwirtschaft, Jena, 1922. English trans. by J. Kahane from the $2^{\text {nd }}$ edn., Socialism: An Economic and Sociological Analysis, London, Jonathan Cape, 1936. In the same theoretical vein, Joseph Stiglitz in our time has laid the failure of the market-socialist experiment (and of communism) to the inefficiencies resulting from its failure to institute suitable incentive mechanisms. See his Whither Socialism? Cambridge, Mass., MIT Press, 1994.

5 Arthur Spiethoff, Jahrbuch fur Gesetzgebung, Verwaltung und Volkswitchaft, 1903. Alvin Hansen marvelously surveys this chapter of economic thought in Ch. 16 of his Business Cycles and National Income, New York, W. W. Norton, 1951. He explains that in introducing knowledge shocks Spiethoff was not repeating - he was paralleling - Michel Tugan-Baranowski's work on financial shocks to investment.

${ }^{6}$ Gustav Cassel, Theoretische Sozialokonomie, Erlangen 1918. English trans. of the 1923 edn., Theory of the Social Economy, New York, Harcourt, Brace and World, 1924, quotation p. 622.
} 
important innovations - those sparked by technological shocks outside markets. ${ }^{7}$

Their work was not fundamentally about capitalism, however. Although their analysis ran in terms of a competitive economy with unfettered firms, they did not imply that economic systems of the capitalist kind were better at seizing the investment opportunities presented. Indeed, they may not have believed that the selection of economic institutions - among capitalist ones or among a broader set with socialist or corporatist ones - was important for the response of economies to new exogenous opportunities. Furthermore, their model did not provide an economics of innovations in normal times, when new commercial ideas are not sparked by the latest technological development but simply draw upon a vast stock of technologies inherited over centuries.

Comparative evidence on dynamism. Empirically, the kind of economic system in place does appear to make a difference for dynamism. A few central European economies twice became laboratories in recent decades for testing competition without private ownership. From the late 1960s to the late 1980s they allowed each state-owned firm to set its own prices, outputs, wages and workforce in competition with the others. Whether or not efficiency improved, it was clear that economic dynamism did not ensue. It was said in defense of these state firms that their managers' plans for them were often blocked by the state and the managers knew they would not be fired for not innovating nor rewarded for innovating so they did not need to. In the 1990s, the state firms were put on their own. This time, with their backs to the wall, they began innovating like mad, hoping that with luck it would be their ticket to survival. But these state firms were not able to innovate profitably. ${ }^{8}$ Competition, it appears, is not sufficient for economic dynamism. Private ownership is necessary (and maybe much more than that).

Recent evidence on corporatist systems, where ownership is private but capital is not very free (entrepreneurs are fettered, financing is distorted, the state is freely interventionist, and more) is also quite negative. The corporatist economies of continental western Europe, which by copying new methods and products overseas posted outsize productivity growth from the mid-1950s even to the early 1990s, thus largely catching up to U.S. productivity in the process, remained impassive when visions of the internet revolution caused entrepreneurs and financiers in the U.S., U.K., Canada - but nowhere in continental Europe - to bolt out the starting gate in the last half of the $1990 \mathrm{~s} .{ }^{9}$ The corporatist economies of east Asia, which achieved wonders as long as there was a wide gap between them and the West, ran into trouble in 1997 when state intervention in their corporate sector through permissions, subsidies and guarantees led to mass overinvestment

7 Phelps and Gylfi Zoega build on Cassel in 'Structural booms,' Economic Policy, 32, April 2001.

8 Roman Frydman, Marek Hessel and Andrzej Rapaczynski, "Why Ownership Matters: Entrepreneurship and the Restructuring of Enterprises in Central Europe," mimeo., February 2000.

9 See Edmund Phelps, 'Europe's stony soil for the seeds of growth,' Financial Times, 9 August 2000. See also sections 1 and 5 of Phelps and Gylfi Zoega, 'Structural booms,' Economic Policy, 32, April 2001. 
and insolvency. ${ }^{10}$ On this thesis, private ownership is not sufficient for dynamism either: Capitalism, in which capital is free to go in new directions without a green light from the state, the community and power blocs, becomes necessary at some point in a country's economic development if dynamism is to emerge.

\section{Schumpeter's extensions of the classical model}

Joseph Schumpeter in his groundbreaking book, first published in 1911, sketched a model of economic change through innovations internal to the markets of capitalist economies: ${ }^{11}$ An innovation was a new commercial development, a "new combinations of productive means," and not to be confused with past inventions and discoveries by scientists and engineers, which were economically barren until subsequent innovations made application of them. Implementation of an innovative project might or might not require hiring scientists or engineers. ${ }^{12}$ These innovations typically arose from perceptions of unexploited business opportunities on the part of business people drawing on their observation of commercial and industrial practice. This view was all the more natural because Schumpeter's innovations included not only new production methods but also new steps on which recent scientific advances might have little to contribute - new goods for consumers, new markets and new business organizations.

In Schumpeter's system, implementation and development for the market of such an innovation required an "entrepreneur" with the "will" to undertake the venture $^{13}$ - generally in "new firms." The impression given is that an innovation may have to wait for an entrepreneur who is in the right place with the needed time and the right stuff. If the stock of innovations made possible by science is advancing without bound, "best practice" methods might forever lag behind the best possible methods. ${ }^{14} \mathrm{~A}$ decline of entrepreneurs or of their entrepreneurship would slow the rate at which innovations were proposed or deemed suitable for backing with new capital. In this system, bankers selected the investment projects to back. Finally, the successful start-ups stimulated other entrepreneurs to imitate and together they caused "creative destruction" of some existing products and jobs in the process of creating new ones.

\footnotetext{
10 This is the hypothesis in Phelps, "Lessons from the Corporatist Crisis in Some Asian Nations," Journal of Policy Modeling, March 1999.

11 Joseph A. Schumpeter, Theorie der wirtschaftlichen Entwicklung (Vienna, 1911; Leipzig, 1912). English trans. from 1926 edn. by Redvers Opie, Theory of Economic Development, Harvard University Press, Cambridge, Mass., 1934, quotation p. 66. By Schumpeter's “model” I mean the stylized relationships and behavior he emphasizes and not the occasional concessions to reality that he makes.

12 "[Although entrepreneurs may be inventors just as they may be capitalists, they are inventors not by nature of their function but by coincidence and vice versa.. . [Thus] the innovations which it is the function of entrepreneurs to carry out need not necessarily be any inventions at all." p. 89.

13 "The individuals whose function it is to carry out [new combinations] we call 'entrepreneurs'." (p. 74.)

The French term entrepreneur, meaning undertaker of a project, was first used in economics by Richard Cantillon and made familiar by Jean Baptiste Say. John Stuart Mill imported it into English and Marshall broadened it to include managers. Schumpeter followed Say. The reference to "new firms" p. 66.

14 Schumpeter notes the implication that ".the 'best method' of producing...is to be conceived as the 'most advantageous among the methods which have been empirically tested and become familiar.' But it is not the 'best' of the methods possible at the time." (p. 83, italics added).
} 
This Darwinesque model of chance mutation and extinction was widely taught and Schumpeter became justly renowned for it. Though many went on viewing entrepreneurship as the earlier Germans did - as merely the unfailing market reactions to new exogenous inventions - Schumpeter had directed a powerful spotlight on the distinct role of entrepreneurs' innovations and the challenge of their peculiar task:

[The] economic leadership [of innovators] must...be distinguished from 'invention.' As long as they are not carried into practice, inventions are economically irrelevant. And to carry any improvement into effect is a task entirely different from the inventing of it, and a task, moreover, requiring entirely different kinds of aptitudes. ${ }^{15}$

[E]very step outside the boundary of routine has difficulties and has a new element.. .[0]utside accustomed channels, the individual is without those data for his decisions and those rules of conduct which are usually very accurately known to him.. .[The entrepreneur] must really to some extent do what tradition does for him in everyday life, viz., consciously plan his conduct in every particular. ${ }^{16}$

Schumpeter thus created new concepts - a gap between "best practice" and perceptions of the "best possible;" innovations, the successful ones of which chip away at closing that gap; and the Schumpeterian entrepreneur, who in deciding on an innovation to undertake plays a role in determining the path of productivity and its industrial directions.

Yet the mechanisms with which he closed his model - how he modeled the emergence of entrepreneurs, the nature of their projected enterprises and the award of funds to submitted projects - are strikingly pre-modern. He supposed that bankers can discern the worth of the projects submitted, just as they would do in the transparency of the classical economy. Implicitly, the ones getting funding are bankable propositions and those unfunded are not.

It is important for the functioning of the system that the banker should know, and be able to judge, what his credit is used for and that he should be an independent agent...[T]he banker must know not only what the transaction is which he is asked to finance and how it is likely to turn out, but he must also know the customer, his business and even his private habits, and get, by frequently "talking things over with him," a clear picture of his situation.. ,[I]f banks finance innovation, all this becomes immeasurably more important.

It has been denied that such knowledge is possible. The reply is that all banks who at all answer to type, have it and act upon it. The giant banking concerns of England have their organs or subsidiaries which enable them to carry on that old tradition: the necessity of looking after customers and constantly feeling their pulse is one of the reasons for the division of labor

${ }_{15}$ Pp. 88-89. 
between the big banks and the discount houses in the London money market. However, this is not only high skilled work, proficiency in which cannot be acquired in any school except that of experience, but also work which requires intellectual and moral qualities not present in all people who take to the banking profession. ${ }^{17}$

Thus the Schumpeterian banker, although exposed to irreducible random influences that may affect an individual project, is safe from the unanticipated consequences that would tend to occur if there was an appreciable degree of "unmeasurable uncertainty" even about whole classes of projects. In this respect, Schumpeter's mechanism is not consonant with subsequent understanding that the finance decision with regard to highly novel kinds of projects is problematic and with the perception that financial institutions may undersupply such projects in favor of some others offering greater "visibility."

Schumpeter's very concept of an innovation is different from that of the theorists in the interwar period. He acknowledges that the entrepreneur's plan "is open.. .to other kinds of errors than those occurring in customary action," presumably errors regarding the costs of design and launch, production cost and user demand. ${ }^{18}$ Yet there is no suggestion that entrepreneurs might be misguided as a group. (Some interpreters of Schumpeter's system even liken his entrepreneurs to people who stumble on five dollar bills on the street.) Moreover, though Schumpeter introduced "innovations" and linked them to people in business, the Schumpeterian entrepreneur seems to be a vessel for acting on information about unexploited opportunities detected and talked about by members of the business community, not generally by the entrepreneur himself.

It is no part of the [entrepreneur's] function to 'find' or to 'create' new possibilities. They are always present, abundantly accumulated by all sorts of people. Often they are generally known and being discussed by scientific or literary writers. In other cases, there is nothing to discover about them because they are quite obvious. It is, therefore, more by will than by intellect that the leaders fulfill their function, more by 'authority,' 'personal weight,' and so forth than by original ideas. ${ }^{19}$ (italics added)

\footnotetext{
17 Schumpeter, Business Cycles: A Theoretical and Statistical Analysis of the Capitalist Process, New York, McGraw-Hill Book Company, 1939. Quotation from the abridged 1964 edn., pp. 90-91. I cannot find any passage on loan decisions in the 1934 English translation of the 1926 edition. And if Schumpeter during the writing had already viewed bankers as an independent factor, that role would surely have been made explicit in the 1911 book. So it appears that Schumpeter tied up the loose end of finance only decades later. 18 P. 85.

19 P. 88. Elaborating on why entrepreneurship is scarce, Schumpeter says that "nobody may be in a position to do it...[I]t is this 'doing the thing,' without which possibilities are dead, of which the leader's function consists. [Even in] a casual emergency, most or all people may see it, yet they want someone [else] to speak out, to lead and to organize." (p. 88) "The entrepreneurial kind of leader-ship.. is colored by the conditions peculiar to it. It has none of that glamour which characterizes other kinds of leadership, it appeals [only in rare cases] to the imagination of the public.. .its success [depends on] a certain narrowness which seizes the immediate chance and nothing else .[and] full appreciation of the service rendered takes a specialist's knowledge of the case. Add to this the precariousness of the posi-tion.. .and the fact that when his economic success raises him socially he has no cultural tradition or attitude to fall back on but moves about in society as
} 
The early moderns emerging a decade later differed radically on the essential nature of innovations - and blurring the sharp distinction Schumpeter had drawn between innovation and invention.

\section{The early moderns' understanding of capitalism and its dynamism}

Conceiving the nature of entrepreneurs' activity was the grand project of Frank

Knight and, later, Friedrich Hayek. As is well-known, it was Knight who in his 1921 book elaborated the distinction between two kinds of risk. there is measurable risk, which is insurable by purchasing an insurance contract from a diversified insurer, and there is what he called uncertainty, which he refers to as "indeterminate, unmeasurable." The latter, usually called Knightian uncertainty, insurers will not touch, since, absent an intensive investigation such as a financier might make, they have no way of typing and calibrating it, so the risk is unknown. The occurrence of a pure profit or pure loss is attributed to Knightian uncertainty, which lies behind the difference "between actual competition and perfect competition. ${ }^{, 20}$ Without that, all income of an enterprise, net of depreciation and any charge for managerial services by the owners, would be essentially interest income. Mere "change" is neither necessary nor sufficient for (pure) profit or loss. ${ }^{21}$

Knight's principal thesis was that, at least in capitalist economies, which are the object of his discussion, the prospects lying ahead for every business decision, including decisions to produce more or less of existing goods, involve elements in the calculation of demand and cost that are not known, not even statistically. Since entrepreneurs starting up a new project must consider far-future projects they especially face Knightian uncertainty.

The universal form of conscious behavior is thus action designed to change a future situation inferred from a present one. It involves perception and a two-fold inference. We must infer what the future situation would have been without our interference, and what change will be wrought by our action. Fortunately or unfortunately, none of these processes is infallible, or indeed ever accurate and complete. We do not perceive the present as it is and in its totality, nor do we infer the future from the present with any high degree of dependability, nor yet do we accurately know the consequences of our own actions. $^{22}$

At the bottom of the uncertainty problem in economics is the forward looking character of the economic process itself. Goods are produced to satisfy wants; the production of goods requires time, and two elements of uncertainty are introduced...First, the end of productive operations must be estimated from the beginning. It is notoriously impossible to tell accurately

\footnotetext{
an upstart, whose ways are readily laughed at. (p. 89-90)." (Later he explains that the interest rate test serves to constrain the rate of innovation to the supply of available saving or what is left after rival sorts of investment have claimed their share.)

${ }^{20}$ Frank H. Knight, Risk, Uncertainty and Profit, New York, Houghton Mifflin, 1921. See 19-20. Nowadays "risk" is apt to designate the first kind of "uncertainty," which is opposite to Knight's terminology.

${ }^{21}$ Ibid., 35-38.

${ }^{22}$ Ibid., 201-202.
} 
when entering upon productive activity what will be its results in physical terms, what quantities and qualities of goods will result from the expenditure of given resources. Second, the wants which the goods are to satisfy are also, of course, in the future to the same extent, and their prediction involves uncertainty in the same way. ${ }^{23}$

The general cause of the uncertainty - the reason why past experience is not sufficient to estimate at all closely the probabilities of the possible future returns on the project - is the endless heterogeneity of past data.

The liability of opinion or estimate to error must be radically distinguished from probability or chance... for there is no possibility of forming in any way groups of instances of sufficient homogeneity to make possible a quantitative determination of true probability. Business situations, for example, deal with situations which are far too unique, generally speaking, for any sort of statistical tabulation to have any value for guidance. The conception of an objectively measurable probability or chance is simply inapplicable. $^{24}$

Knight in an insightful discussion argues that the "producer" rather than the consumer bears the uncertainty.

[T] he consumer does not even contract for his goods in advance, generally speaking. A part of the reason might be the consumer's uncertainty as to his ability to pay at the end of the period...[but] the main reason is that he does not know what he will want, and how much, and how badly; consequently he leaves it to producers to create goods and hold them ready for his decision when the time comes...[A]n outsider [such as a producer] can foresee the wants of a multitude with more ease than and accuracy than an individual can attain with respect to his own. This phenomenon gives us the most fundamental feature of the economic system, production for a market ${ }^{25}$ Some people are better at making entrepreneurial judgments or have more confidence in their judgments or positively like to work on "original" projects and seem "to prefer rather than shun uncertainty." (p. 242.) These people typically bear the uncertainty.

In [a handicraft] system every individual would be an independent producer...[But it] passes over into a system of "free enterprise" which we find dominant today. The difference between free enterprise and mere production for a market [is]...specialization of uncertainty-bearing. [The anticipation of wants and control of production with reference to the future], already removed from the consumer himself, is further taken out of the hands of the great mass of producers as well and placed in charge of a limited class of "entrepreneurs" or "business men." 26

Finally, investors and lenders helping to finance a new project have the possibility

23 Ibid 237-238.

24 Ibid. 231.

25 Ibid. 241.

26 Ibid. 244. 
of spreading the uncertainty by diversifying their investments and loans over several or many producers.

The minute divisibility of ownership and ease of transfer of shares enables an investor to distribute his holdings over a large number of enterprises...[T]he losses and gains in different corporations must tend to cancel out in large measure and provide a higher degree of regularity and predictability in his total returns. And.. .the chance of loss of a small fraction of his total resources is of less moment even proportionally than a chance of losing a larger part. ${ }^{27}$ Today, it might be commented, "structured," or "layered," contracts carve out pieces of the project - both equity and debt instruments - that specialized financial entities such as hedge funds and pension funds find well suited to their needs. Moreover, the start-up entrepreneur stands to lose his equity stake and his control of the enterprise if targets set by the investors and lenders are not met. So, as in Knight's day, entrepreneurs must bear plenty of uncertainty.

Thus Knight's Risk gives a deep analysis of the radical uncertainty that is a distinctive, pervasive and central feature of capitalist economies. But although his portrait of capitalism may be logically complete, it leaves out something too big to be a telling likeness of capitalism. Innovation - therefore creativity in business, the novelty possessed by many new proposals, the asymmetry of information about them, and the expansion of knowledge that may result - never comes to have a central place in Knight's model of capitalist economies. In a passage late in the book he takes up - generally from the view of its relation to uncertainty - the presence of (new) knowledge, "or what may be designated by the term 'invention' in the broad sense" (p. 339). He acknowledges that there is "discovery" and there is "creation" (p. 340) - the latter a "result of deliberate thought, investigation and experiment" (p. 341). But this fleeting allusion to knowledge formation was too thin and too late to have an impact on thinking about innovation. ${ }^{28}$

John Maynard Keynes entered the stage about the same time as Knight and some of his enduring insights complemented those of Knight. Keynes's book on probability theory was aimed at understanding decisions under unmeasurable uncertainty. ${ }^{29}$ His contribution was to show that a rational response to such uncertainty was to behave as if the probabilities of the explicit possibilities summed to a number less than one, thus leaving room for the sense that there were contingencies not identified or not fully appreciated. His recognition of the uncertainty that faces entrepreneurial projects was to carry over to the

\footnotetext{
${ }^{27}$ Ibid. 254.

28 Where Knight says that "some individuals want to be sure.. .while others like to work on original hypotheses" (p. 242) he means for all we know that some business people prefer to manage, say, an existing power company, with all the uncertainties it may hold in store, while others would prefer the uncertainties of starting up a new power company. The "original" project may mean nothing more than trying the ith project that some concept suggests would find a profitable market after the previous $i$ - 1 projects based on the same project have succeeded.

${ }_{29}$ Keynes, A Treatise on Probability. London, Macmillan, 1921.
} 
macroeconomics of capitalist economies that he started in the mid-1930s. ${ }^{30}$ His famous allusion to "animal spirits," a term of Plato's, behind businessmen's investment decision-making served to underline his view that the volume and directions of entrepreneurial projects and of investment projects in general depended heavily on the entrepreneur's instinctive feeling about what the future would hold for the project, not just on financial and engineering data. Finally, it was Keynes who first emphasized that, in an entrepreneurial economy at any rate, the uncertainty of the future inevitably leads to diversity of opinion about where prices might go and where profits might lie; yet rules of thumb may prevail in some markets, making prices there quite sluggish until one or more developments make some things clearer - and, possibly, a new rule of thumb begins to form. ${ }^{31}$

Incidentally, though it is a long story, it is fair to say that, in an age - the 1920s - when Lenin was constructing a communist economy in Russia and Mussolini a corporatist one in Italy, Keynes stayed on the side of capitalism. ${ }^{32} \mathrm{He}$ opposed laissez-faire (the "free market" in English), believing that the state has useful functions to play, had a low regard for wealth accumulation and a distaste for money grubbing. But for him these were not essentials of capitalism. Certainly he saw the depression that struck Britain and the U.S. in the interwar period as signaling a serious lapse in capitalism's performance and he tried hard erge $\mathrm{He}$ thought that capitalism remained valuable as an engine for generating commercial innovation and thus raising productivity. Capitalism will survive in a country as long as people's ideas of a good economy allow it. "The world," he said in answer Marx, "is ruled by ideas and little else.",33

Hayek comes in where Knight and Keynes leave off. Hayek, beginning in the second half of the 1930s, emphasized the untried and thus the speculative nature of what the entrepreneur with a new project is attempting, introduced in the mid-1930s a distinction between two kinds of knowledge. ${ }^{34}$ In the classical view, knowledge is unambiguous and complete, so its implications are fully determinable. There is no sense of knowing there are things we do not know, things we may come to know eventually and things we will never know. In the modern view adopted by Hayek, actors in the world have to make judgments that are not fully implied by their formal models. As Keynes wrote, "It is necessary finally to act." And that requires them to draw upon their tacit, or personal, knowledge: "We know more than we can say," in the aphorism of Michael Polanyi. In the growth-of-knowledge theory of Hayek and Polanyi, formal knowledge advances in the sciences as scientists combine their current tacit

\footnotetext{
30 Keynes, The General Theory of Employment, Interest and Money. London, Macmillan, 1936.

${ }^{31}$ Keynes, "The General Theory of Employment," Quarterly Journal of Economics, 51, February, 1937.

${ }^{32}$ To digress more, in the late 1930s he objected to the expense of Beveridge's plan for a welfare state and in the 1940s he teased Hayek for extolling individualism while proposing state healthcare and other activities.

33 Keynes, The General Theory.

34 Hayek, Collectivist Economic Planning, London: George Routledge, 1935, and Hayek, Individualism and Economic Order, Chicago, University of Chicago Press, 1948.
} 
knowledge with existing formal knowledge in conceiving and selecting hypotheses to test and experiments to make. ${ }^{35}$ That is how formal knowledge advances.

Hayek then applied this growth-in-knowledge theory to the activities of innovation and discovery in capitalist economies. The entrepreneurs come to their distinctive judgments through their distinctive personal experience and resulting personal knowledge, or "know-how" in his terminology. Similarly, the technical work in engineering and marketing a new products or methods involves personal knowledge. "[M]uch of the knowledge that is actually utilized is by no means 'in existence' in [a] ready-made form. Most of it consists in a technique of thought which enables the individual to find new solutions." ${ }^{36}$ Thus capitalist economies generally draw on a diversity of tacit knowledge that in the aggregate is vastly more than any one banker or shareowner or central planner could possibly possess or even conceive of. (Hayek held that since innovations entail creative leaps and invariably these leaps involve tacit knowledge, which is outside recognized knowledge and hence goes beyond what can be communicated in explicit terms, a state investment bank would not be well-suited to select among entrepreneurs' projects: Being accountable to the central government for its mistakes, it would avoid all the very innovative proposals because of the ambiguity of the evidence for them and the consequent impossibility of communicating their appeal to higher authorities or to the public.)

It follows that the many lenders and investors selecting among entrepreneurs' projects in a capitalist economy are also, like the entrepreneurs, not immediately able to grasp the worth of every entrepreneurial project offered for financing. Thus financiers must also depend in part on their intuition, deciding to take or not to take an initial and limited chance on an applicant in spite of the ambiguity of the evidence. If the typical innovative project is in part inherently not capable of being articulated, how successful the bankers and venture capitalists prove to be in selecting among them hinges not only on the partial and tentative understanding they initially acquire about the entrepreneurial projects submitted to them but ultimately also on the willingness of the entrepreneur to enter into a provisional relationship with the entrepreneur that provides the entrepreneur with some leeway to experiment and prove himself and thus the financier to acquire more knowledge about the project. This is a far cry from Schumpeter's "bankable propositions."

It further follows that the success of an innovation remains a matter of considerable uncertainty until it is determined by the reception it finds among

\footnotetext{
${ }^{35}$ Three classic references are Friedrich A. Hayek, "The Use of Knowledge in Society," American Economic Review, 35, 519-530, 1945; Hayek, "Competition as a Discovery Procedure (1968)," New Studies in

Philosophy, Economics and the History of Ideas, Chicago, University of Chicago Press, 1978; and Michael Polanyi, Personal Knowledge, Chicago, University of Chicago Press, 1962.

36 Hayek, "Socialist Calculation II: the State of the Debate," in Collectivist Economic Planning, London: George Routledge, 1935, reprnt., Individualism and Economic Order, op. cit., p. 155.
} 
potential users in the marketplace. As Hayek must have enjoyed commenting, the strength of the demand for the novels of C. P. Snow could not be known beforehand, not even by the author himself, until they were produced and offered to the book-buying public. ${ }^{37}$ Every innovation is like a scientific experiment in which, characteristically, the probabilities of the various results are not determinable beforehand - nor fully determinable afterwards either.

The potential users themselves may have little idea how much they will like the new product or method unless and until they try it. (Users cannot plausibly be assumed to know that a priori if, as Hayek supposed, the entrepreneur, who is an expert and himself a consumer, does not know he has anticipated all the things that might deny him success.) Thus households and firms deciding on a new product or method have the same knowledge problem as do the entrepreneur and financier behind the product or method. Economies of dynamism are shot through with Hayekian knowledge formation.

One other point. If the individual upstart entrepreneur is central to innovation, how can we resolve the puzzle that would have troubled Mises: Large firms are bureaucratic and, especially in the U.S., typically owned by passive shareowners so they do not usually have a principal lender or core investor who could choose in-house "intrapreneurs" to back and advise on their innovative projects. Yet the large firms account for the lion's share of the industrial research and seemingly of innovation as well. The resolution may be that the new and successful ideas of the start-up entrepreneurs owe most of their further development and possible extensions to high-capital-cost projects at the large firms - including the large firms that the start-up firms sometimes grow to be and the large firms that buy up successful start-up firms. If the germinal material for innovation by large firms is the underdeveloped innovations of recent start-ups, models of large-firm innovation based on the "defensive innovation" of the 1942 Schumpeter, "work" only thanks to the stimulus of the 1911 Schumpeterian start-ups. The interplay between the small-firm sector and the large-firm sector perhaps overcomes the bureaucratic organization of the large corporations, especially public companies.

Knight's recognition of the uncertainty surrounding business decisions and Hayek's bottom-up theory of discovery and growth of knowledge have ramified over a wide range of subjects and influenced many economists and political scientists, including Jane Jacobs, Milton Friedman, Michael Oakeshot and James C. Scott. ${ }^{38}$ Yet the conceptual advances of Hayek, Knight and Keynes on

\footnotetext{
37 Hayek, "The Non Sequitur of the 'Dependence Effect'," Southern Economic Journal, April 1961, repmt. Phelps, ed., Private Wants and Public Needs, New York, W. W. Norton and Co., 1962.

38 Jane Jacobs, The Death and Life of Great American Cities, New York, Vintage Books, 1961; Milton Friedman, Capitalism and Freedom, Chicago: University of Chicago Press, 1962; Michael Oakeshot, Rationalism in Politics, New York, Basic Books, 1962; and James C. Scott, Seeing Like a State, New Haven, Yale University Press, 1998. (Referring to medical practice, Friedman wrote “...[A] faith healer may be just a quack who is imposing himself on credulous patients, but maybe one in a thousand or in many thousands will
} 
innovation and dynamism are little imbedded into formal models and thus into orthodox theory. No doubt further effort is needed.

This survey virtually stops here not on any perception that no further core developments in the subject occurred in the second half of the $20^{\text {th }}$ century (other than Hayek's last writings) but because an adequate review would involve a much larger cast of contributors - and much less radical contributions - than are found in the interwar period. Yet I can refer readers to the seminal, contributions that stand out in my mind among an undoubtedly larger number that would deserve equal mention. There is the contribution by Schumpeter in the war-time and early postwar years in which he argued that oligopolists are motivated to engage in defensive innovate in order to avoid losing the profits they already have from their market share, a thesis recently taken up by William Baumol. ${ }^{39}$ Another is the work by Richard Nelson and Thomas Marschak arguing that financiers can largely meet the problem of having far from complete knowledge about one or more key parts of an entrepreneurial project by entering into an agreement that metes out the finance sequentially upon the entrepreneur's meeting successive benchmarks. ${ }^{40}$ The Nelson-Phelps model has reverberated in recent years not only for its much-tested implications about the role of education but also because it implies that entrepreneurs will be reluctant to develop and market an innovation in a market where few potential adopters are highly educated. ${ }^{41}$ Another salient contribution is the work by Amar Bhide in which it is argued that small firms have a distinctive role in innovation owing to their advantage in coping with Knightian uncertainty and large firms have a distinctive role in innovation owing to their advantage in managing and financing projects with high capital costs. ${ }^{42} \mathrm{~A}$ significant portion of the economics we have to date about evolving economies is presented in the book by Nelson and Winter. ${ }^{43}$ There is also the work of recent years by Roman Frydman and Michael Goldberg developing an economics applicable to an economy where there is inherently imperfect knowledge about its current structure and how it unfolds over time. ${ }^{44}$ Finally my recent work argues that economics has failed to take into account the benefits of economic dynamism in modeling and evaluating capitalism: The philosophy called "vitalism" implies

\footnotetext{
produce an important improvement in medicine. The effect of restricting the practice of what is called medicine...is certain to reduce the amount of experimentation that goes on and hence to reduce the rate of growth of knowledge in the area." p. 157.)

39 Schumpeter, Capitalism, Socialism and Democracy, New York, Harper and Brothers, 1942; $2^{\text {nd }}$ enlarged edn. 1947. See also William J. Baumol, The Free-Market Innovation Machine: Analyzing the Growth Miracle of Capitalism, Princeton, Princeton University Press, 2002.

40 Richard Nelson and Thomas Marschak, "Flexibility, Uncertainty and Economic Theory,"

Metroeconomica, 1962. Of course, the financiers may nevertheless have to choose their entrepreneurs in the dark to start with and that may deter a large quantity of finance.

41 Richard R. Nelson and Edmund S. Phelps, "Investment in Humans, Technological Diffusion and Economic Growth," American Economic Review Papers and Proceedings, May 1966.

42 Amar V. Bhide, The Origin and Evolution of New Businesses, Oxford, Oxford University Press, 2000.

43 Richard Nelson and Sidney Winter, An Evolutionary Theory of Economic Change, Cambridge, Mass., Harvard University Press, 1982.

44 Roman Frydman and Michael Goldberg, Imperfect Knowledge Economics, forthcoming, Princeton University Press, 2007.
} 
that the processes of problem-solving and discovery are an end, or reward, in themselves, not just a means; high productivity derives much of its social utility by enabling more people to afford taking jobs that are rewarding in those non-pecuniary ways. ${ }^{45}$

\section{A Rudimentary Framework for Theoretical Study of Innovation}

I want to sketch here the core element of a model capturing the essential aspects of a capitalist economy in the sense of an economy driven by proposals of private business participants to private financiers for backing of innovative projects. The first objective is to construct in broad outline a micro-founded model of the mechanism governing what we might call the "flow-supply" of new ideas to the innovation market coming from entrepreneurs and the "flow-demand" from financiers. The subsequent objective is to consider, albeit somewhat informally in the present paper, how certain market forces that would otherwise not be present such as the circumstances and expectations of entrepreneurs and those of financiers - affect the outcome of their interaction. It will be a source of satisfaction to have market models of the supply of entrepreneurial ideas to the market and their selection, or demand, by financiers, since innovative ideas are central to business life in a capitalist economy. Furthermore, having such a component in our larger model of the economy may help us organize hypotheses about how an economy's performance is impacted by the institutions and other conditions impacting on some of the central figures generating (or failing to generate) dynamism - the entrepreneurs and the financiers. We have to study the entrepreneur as a micro actor and to study the entrepreneurial economy as an interactive system involving entrepreneurs and financiers. (This first pass, though, avoids the richness of institutions found in real capitalist economies.)

\section{The construct of an "innovation fair"}

The classic supply-and-demand apparatus does not apply to the core market of capitalist economies - the capital market, particularly the market for capital going to entrepreneurs' innovative projects. The least of the complications is that every entrepreneurial project is a different good, just as every new house placed on the market differs from the others. That each entrepreneur's idea is idiosyncratic, hence unique, does not by itself preclude a manageable model of equilibrium.

Let me in the interest of simplicity introduce a construction that reflects the fact that an economy is spread out over space, so the economy's actors are not ordinarily in contact with large numbers of others, yet they can convene with others intermittently for purposes of important transactions. I will suppose that periodically - once every 5 years, for example - all the entrepreneurs who in the previous period have hit upon a new idea they regard as worth the trip travel to a

45 "The Economic Performance of Nations: Prosperity Depends on Dynamism, Dynamism on Institutions," in E. Sheshinsky et al. (eds), The Growth Mechanism of Free Enterprise Economies, Princeton, Princeton University Press, 2006. 
sort of fair to seek financing. A comparable number of financiers, each with a large pool of liquid capital, attend the fair to seek entrepreneurial projects to invest in or make loans to. They are the abstract counterparts of today's hedge funds and venture capital funds. ${ }^{46}$ (I was delighted to learn about a year ago that such fairs actually take place! The entrepreneurs reportedly remain stationary while a procession of the financiers circulates around them.) Once they contract to finance a project they will act as partners of the entrepreneur, drawing on their generally different experience to solve problems in the development and launch of the new product or method. With the project's completion the financiers will sell their shares in an IPO on the stock exchange and their bonds on debt markets.

It might be thought that the capital-market model devised by Irving Fisher and James Tobin, originally applied to many heterogeneous investment projects, could be a satisfactory tool to analyze this innovations market. ${ }^{47}$ Whether applied to investment projects or to innovation projects, that model implicitly supposed that there is no ambiguity about the promise of each such project. As a result there is agreement among the financiers about the value of each project: it is the present value of the agreed expectations of the stream of future gross earnings it would generate. The investment cost of each project is also a given. It then followed, as Tobin showed, that the capital market would rank highest for financing the project(s) with the highest calculated value per dollar of investment cost; would rank second-highest the project(s) with the next highest ratio of value to cost; and so forth until there were no more projects with a positive rent - with a value-to-cost ratio (Tobin's $Q$ ratio) greater than one. An inframarginal entrepreneur collects from his financier(s) a rent that, added to the above investment cost, leaves her (the financier) with the same zero expected profit on that investment as would be expected on the marginal project.

I would comment that such a Fisher-Tobin equilibrium may exist even if the profitability of each project is subject to exogenous sources of uncertainty (i.e., Knightian uncertainty in which no one knows the probabilities of all the various conceived outcomes or even knows all of the possible outcomes there are). An unambiguous ranking of projects would still exist if some war of unknown probability would be expected by all, should it occur, to reduce the value of all projects in equal proportion; in that case the ranking would not even be affected (though fewer projects might make the cut). More generally, a ranking would still exist if it is understood that exogenous shocks of unknown probability would impact unequally on the values of the various projects, provided the financiers are alike in their judgment of those impacts and the weight they give to the shock and their judgment of those impacts and the weight they give to the shock.

But complications set in once we recognize, following Hayek and Polanyi,

\footnotetext{
46 A hedge fund marks to market its assets, so its investors have an idea of the price they could expect for their shares if they decide to leave the fund. Investors in a venture capital fund are more nearly locked in.

47 I. Fisher, [to be supplied], and J. Tobin [to be supplied].
} 
that the entrepreneur's idea presents some ambiguity-. The entrepreneurs are to some extent like the fighter pilots: unable to explain the thinking behind their decisions. ${ }^{48}$ So, in any brief initial interview, the financiers can see only dimly what each idea is, what would be involved to implement it, and what the selling points and the snags might be if it were marketed. Moreover, since financiers weighing projects have to use their own limited experience and specialized knowledge, and these differ from financier to financier, the financiers do not all make the same valuations. Hence, even if each financier falls into a group of like-minded financiers each of whom views the entrepreneurs' proposals the same way, one such group might rank the projects differently from another. So if we are to build a usable model of the intersection of the entrepreneurs' projects and the financiers' capital it is necessary to see whether disagreements in financiers' rankings are apt to be a barrier to the conclusions we might hope to reach.

To narrow down possibilities I propose to give the model more structure by supposing that each financier prefers to back the idea of an entrepreneur whose "model" is most resonant with his own - his thinking with regard to which industry is the best bet, swinging for the fences or not, and so forth. ${ }^{49}$ So the "capital market" is a sort of matching process that matches a financier to an entrepreneur who the former sees as having a model compatible with his own model. Thus capitalism is a system producing a profusion of ideas representable as competing models of the economy (or a piece of it) and when an entrepreneur and financier sense they have roughly the same model they band together in a bet on its ability to prove itself. In this way the financiers are matched to the entrepreneurial projects to which their collaboration can contribute the most in view of their nearly identical outlook.

After the entrepreneurs have had their initial interviews, some of them will generally enter into a further discussion and that may lead to a letter of intent, called in the trade a terms sheet, from a financier (and her possible partners). The penalty for withdrawing from such a commitment makes it quite unlikely that the financier will fail to sign the indicated contract and choose instead to send a new letter of intent to another entrepreneur. Entrepreneurs who do not receive or do not accept such letters leave the game, their project having failed to gain finance.

\section{Equilibrium and disequilibrium in the innovation market}

To discuss forces acting on equilibrium and departures from equilibrium we need to define it. As I customarily do, I will use the expectational definition of market

\footnotetext{
48 The post-Polanyi literature includes Hubert Dreyfus, What Computers Still Can't Do (Cambridge, Mass., MIT Press, rev., 1979) and Gary Klein, Sources of Power: How People Make Decisions (Cambridge, Mass., MIT Press, 1998).

49 The Bradley brothers, two celebrated entrepreneurs in Minneapolis some decades ago, remarked on precisely this core aspect of entrepreneurship (without benefit of reading Hayek, so far as I know). "The entrepreneur," they wrote, "invents a new model of the world from which he derives his new business project.” (Quoted by memory from documents ca. 1998.)
} 
equilibrium, which was originated by Marshall and Myrdal. I use a macroesque version of this equilibrium, referring to representative agents. And I put intertemporal considerations aside, leaving intertemporal equilibrium as a separate concept.

Such an equilibrium in the innovations market requires that the entrepreneurs as a whole are not overestimating the average value per investment dollar being placed on the projects of the other entrepreneurs, so the entrepreneurs are not being misled by such an expectational error into holding out for higher terms than they would otherwise do; similarly, the entrepreneurs as a whole are not underestimating the average value per investment dollar. This equilibrium also requires that the financiers as a whole are not overestimating the average value per investment dollar that the other financiers are offering, so the financiers are not being misled by such an expectational error into offering higher terms on the projects they want than they would otherwise do; similarly, the financiers are not generally underestimating the average value per investment dollar. ${ }^{50}$ Obviously the case of equilibrium case does not rule out that some entrepreneurs have been misled by his or her expectations about the outcomes on the market; it only specifies that the errors have roughly canceled out - that the representative entrepreneur has not overestimated the demand for his project by financiers.

This expectational equilibrium does not imply market clearing. Indeed it is reasonable to suppose that, even if their market expectations (just discussed) were correct, some of those entrepreneurs were overly bullish about the appeal of their own project and some subset of these entrepreneurs finally found themselves having no more offers to agree to. Although they may have made successive inferences leading to successive reductions of their "acceptance price," not all of them necessarily reduced their acceptance terms fast enough to avert the result that their projects are not under contract by the time all the financiers have committed all or nearly all their funds on other projects. (There is no "recontracting" here. The discussion after the initial interview that may lead to letters of intent may have high opportunity costs, so that penalties are provided for withdrawing from a commitment.) A rather different point is that an entrepreneur may be willing to gamble on holding out for a price above his reservation price, knowing that he is not facing perfectly elastic demand. (In reality, entrepreneurs can also wait for the next fair, which some do.) So our equilibrium is of the non-market-clearing kind, which is familiar in labor-market models.

Another observation is that even if the innovation market finds equilibrium, it does not follow that this equilibrium is completely independent of which transactions happen to be made early as one project after another is adopted by financiers: path dependence is conceivable and no doubt possible. Owing to the

\footnotetext{
50 The above requirements for equilibrium in the innovation market capture the spirit of the concept, even if it should be found that some further requirements are appropriate to add.
} 
Hayek's point that much of the entrepreneur's understanding of his proposed innovation is personal knowledge, a financier will have far from complete knowledge about it and will have little idea of what any other person's knowledge about it is. Thus there may be learning in this regard over the course of the market's allocations of projects and the information on the terms at which they are sold. Further there may be some chance factors influencing whether or not some subset of projects are bought up early. So the future of the bidding may depend to some extent on which projects happen by chance to be sold early in the process. So the equilibrium in the market for these Hayekian objects may not be uniquely determined. However, the possibility that there is some indeterminacy around the equilibrium and maybe not pure white noise should not deter us from investigating the effects of forces acting on equilibrium and the effects of disequilibrium as long as the answers to the questions asked are not sensitive to the particulars of the equilibrium that is or would have been reached.

\section{What drives financiers to back any innovation at all?}

It is perfectly natural to wonder whether an equilibrium in this innovation market is necessarily one in which a positive number of projects win financing. Maybe it is only because entrepreneurs can finance themselves or they are friends or relatives of a financier that they can get their projects going. On this issue, I would argue that even in the case of perfect ignorance on the part of the financiers - so that financiers were unable to distinguish one entrepreneur's project from another (and one entrepreneur's character and talent from another's) - financiers would generally supply some financing and some innovation will go ahead. My argument is this: If all the new projects offered looked the same to financiers, applications of pseudo-entrepreneurs would explode if Tobin's $Q$ ratio exceeded one or even equaled one, since a great many people would prefer being an entrepreneur to being a salaried employee - especially an entrepreneur paid an entrepreneur's wage. So the expected $Q$ ratio in every period would have to lie in a range below one. And if the entrepreneurs valued projects only for the positive rent they received from it - the rent consisting of the excess financiers pay over the investment cost (figured at market wage rates) - then none of the innovative projects would be undertaken. But if there are some entrepreneurs who estimate highly enough the non-pecuniary satisfactions that would accrue from doing their project (the thrill of it, the learning experience) and if these entrepreneurs would acordingly subsidize the project with a reduced salary in order to fill the gap between the investment cost (figured at normal salaries) and the deficient valuation put on their project by financiers, then they will be able start their projects. If the promise of entrepreneurs to work at subsidized wage rates out of professed love of their work looks to be incentive-incompatible (maybe the entrepreneur will restore his wage, causing the financier's returns to suffer), the entrepreneur may be able to signal his love of the project by investing resources of his own or family members in spite of the less-than normal rate of return that is expected. (For what it is worth, James Tobin told me at Yale that Schumpeter believed that entrepreneurial 
projects earned a below-normal rate of return. I have not found that in print though.)

A more general point here is that in any case - the case of financiers' perfect ignorance and the case of financiers' initially imperfect knowledge - some portion of the entrepreneurial activity taking place is the result of the large concessions (in returns or leisure sacrificed) that some of them, whether or not all, make through their own labor or on their own capital investment in order to save the project and thus have its nonpecuniary satisfactions. ${ }^{51}$ If that is so, the supply side of entrepreneurial projects is more important than it is perhaps generally understood to be. The supply price (or reservation price in other terminology) at which he will supply the attention and concentration necessary for conceiving of the entrepreneurial idea will be lower the higher are those expectations. Moreover, once the project has been conceived, the acceptance price that the entrepreneur requires to let it go to the prospective financier (rather than hold off for a better offer) will also be lower the higher his expectations of the project's nonpecuniary reward to him. The latter is in contrast to the "textbook" model: In the Fisher-Tobin model of investment, which can be applied in principle to investing in new products and methods, an entrepreneur with his already conceived project is activated, or deployed, by the financial sector if and only if its expectations of the value of the entrepreneur's project exceeds the opportunity cost of the project; the entrepreneur's expectations do not figure in. (That is, existing projects are supplied perfectly inelastically.)

Comparative statics: expected reward, wealth, economic culture, institutions The perspective of the market model I have been using here suggests to me four exercises that may be useful to get a sense of how the "model" works.

First, as implied in the just previous discussion, entrepreneurs 'expectations of the nonpecuniary rewards from entrepreneurial labor and their expectations of the pecuniary rewards from their own capital investment in the project matter for the volume of entrepreneurial activity - that is, the volume of projects started - not just financiers' expectations. My own macro models would then lead to the corollary that that the expectations of both actors matter for the determination of total business activity, as measured by total employment. To be definite, improved expectations of entrepreneurial job satisfaction would operate to increase the number of entrepreneurs supplied to the market (i.e. the fair). And the acceptance wage would presumably shift down. The "incidence" would include a reduced pecuniary wage and an increase volume of entrepreneuring. (I would note parenthetically that an optimal contract between entrepreneur and financier will reflect any difference of optimism between entrepreneur and financier. Standard contract theory implicitly posits that the parties to a contract share the identical

51 Their overly enthusiastic forecasts of the rate of return on investments in the project will also tip them toward accepting worse terms from financiers to get the project over the top. 
"rational expectations," since they have the identical model of the world. Work in that vein does not fit in a theory of capitalist economies, in which views are never homogeneous and may be wildly diverse.)

An increase in the expected pecuniary reward, which is the expected entrepreneur's wage after any concessions made to obtain financing, is not exactly analogous to the an increase in the non-pecuniary reward. But an increase in pecuniary reward net of the concessions, meaning a decrease of the necessary concessions, is analogous. If the market for innovations becomes stronger, so that entrepreneurs need offer a smaller concession to draw financing, that would increase the number of entrepreneurs supplied.

Second, the wealth of entrepreneurs and that of financiers also matter for the level of entrepreneurial activity and as a consequence for total business activity. If the size of the concessions that some or all entrepreneurs would be willing to make upon sensing that their project was turning out to be marginal are a "normal good," so that a given entrepreneur would have a lower supply price (or reservation reward) the wealthier he is, an increase of his wealth operates to shift outward (and downward) the supply curve of entrepreneurs willing to develop projects at any given price or reward; on this account, taken alone, the increased wealth would expand the number of projects offered to the market and thus the number started up. On the other hand, greater wealth could have the opposite effect of reducing the zeal of the potential entrepreneur to gamble on coming up with a project bringing big nonpecuniary or pecuniary reward. Moreover, the same increase in wealth could shift up the acceptance price, since the wealthier entrepreneur can better afford to wait, which operates to contract the number of projects started up in our equilibrium model. So the end result of higher wealth among entrepreneurs is in doubt on two counts. But what is noteworthy is the implication that increased wealth could deter innovation by making potential entrepreneurs less keen and make those who do develop projects more choosy about the deal.

An increase in the wealth of financiers or of the depositors who invest in the venture-capital and hedge funds run by the financiers may boost the demand for entrepreneurial projects, i.e., boost the supply of finance. My long-time collaborator Hian Teck Hoon points out that if the economy is coming off an innovation-based boom in which a generation of entrepreneurs have made a great deal of money, that may boost the supply of finance to the next generation of entrepreneurs.

The modeling and the statistical investigation by Aghion, Howitt and associates proposes a somewhat similar yet distinct hypothesis: the credit worthiness, or credit line, that an entrepreneur has may be roughly proportional to the entrepreneur's wealth. That mechanism leads the authors to the theoretical implication that increased wealth is positive for entrepreneurial development 
activity and the resulting rate of innovation. ${ }^{52}$ The statistical findings in recent papers support their hypothesis. But it remains to be seen whether increased wealth in the wealthy economies promotes innovation. (But see discussion below involving incentive-type contracts.) In any case, the framework here by itself poses a potential conflict between wealth's effect on the supply of projects, which is potentially negative, and its effects on the demand, which is presumably positive. Provisionally, I incline to see wealth in relation to wage rates as, on balance, a drag on entrepreneurial projects, especially start-up projects, in part because such a drag may be one of the few mechanism governing a country's rate of innovation. A plausible hypothesis, for example, is that activity rates of all kinds, including rates of entrepreneurial activity, wane as wealth climbs relative to wage rates. Whether the U.S. record in the past half-dozen years is an important outlier for that hypothesis remains to be determined.

Third, there is the implication that a country's economic culture may play a part in the determination of the volume and quality of entrepreneurial activity. The inclination of would-be entrepreneurs to avoid nonentrepreneurial jobs in the production of already existing consumer goods in favor of entrepreneurial jobs in the development of new goods causes a contraction of the supply of consumer goods and an expansion of the supply of entrepreneurial projects (with corresponding effects on interest rates and wealth accumulation). Hence, it is not obviously bad economics to admit the possibility that some economies, for example those in western continental Europe, suffer low entrepreneurial activity not solely because of costly impediments to entry etc. or poor financial institutions but because they have a low level of "entrepreneurial spirit." (The possibility this is so does not mean it is so, of course.) Furthermore, there is the possibility of variability through time in the strength of this spirit, even wide mood swings. ${ }^{53}$

The "spirit" of financiers also comes in as an influence on the valuation that a financier puts on a potential entrepreneurial project. Here, of course, the financiers' willingness to endure Knightian uncertainty is important. That does not mean, though, that low share prices, for example, are a sure sign of high aversion to uncertainty. The question is the demand price at some reference level of the innovation volume, possibly measured in persons engaged in innovational activity. One has to estimate and compare across countries the demand schedules for innovation. A low demand in the schedule sense may be the result of an culture hostile to innovation. Or it may instead be evidence of economic institutions adverse to innovation.

\footnotetext{
52 See, for example, Philippe Aghion, Peter Howitt and David Mayer-Foulkes, "The Effect of Financial Development on Convergence [of the Productivity Growth Rate]: Theory and Evidence," Quarterly Journal of Economics, 120, February 2005, 173-223.

53 An example is Martin Wiener, English Culture and the Decline of the Industrial Spirit, Cambridge University Press, 1981. See too Mancur Olson, The Rise and Decline of Nations, Yale University Press, 1982.
} 
Last, the framework is compatible with influences from existing economic institutions. Obviously, hindrances to entrepreneurs will translate into lower forecasts of the profitability of available entrepreneurial projects and thus curtail the number of projects receiving finance. Institutional inefficiencies and deficiencies clearly also impact on the demand curve for innovations.

\section{The structuring of innovation finance}

I want to touch on another aspects of the interaction of partially ignorant financiers with entrepreneurs bearing new projects - the sort of contract between entrepreneur and financier that would create suitable incentives for the entrepreneur in the present context where the financier faces the ambiguity of what the entrepreneur is able and willing to explain. Would a suitable contract entail bond financing by the venture capitalist or other financier? Or, say, convertible preferred stock? Or what? Relatedly, do contracts that provide a suitable "incentive reward" have the effect that "incentive wages" have in the labor market - namely, to lead to better incentives though at the cost of creating an equilibrium at non-market-clearing terms? This is part of the ground being explored in work that Max Amarante and I are currently doing.

Tentatively, it appears that neither complete reliance on convertible preferred stock nor complete reliance on debt finance nor on a combination of the two can perfectly align the interests of the entrepreneur and the financier. An optimal contract is not knowable in an exact way. But maybe the features possessed by an optimal contract, in very simple settings at any rate, could be deduced.

It is also beginning to appear that, from the point of view of incentive theory, the lead financier can be expected to offer the entrepreneur incentive arrangements not offset by a compensated decrease of the entrepreneur's salary. Can it be formally argued that financiers drive up the terms of the standard contract in an attempt to give the entrepreneur something to lose if his estimated efforts or acumen are found deficient, which makes financing more expensive than is portrayed in a neoclassical (Fisher-Tobin-type) theory, so that there will be fewer entrepreneurs financed per financier and in toto? The answer would seem to be yes, generally speaking, in so far as the incentive arrangements are a second-best deterrent to the entrepreneur's self-dealing in ways that are difficult or impossible to "monitor" or detect. ${ }^{54}$ (But I would add that the presence of performance-related bonuses does not necessarily lead to a failure of the market for entrepreneurs to "clear," just as the practice of paying according to output ("piecework") does not lead to involuntary unemployment.)

Regarding incentive-compatible contracts, it should be remarked that they

\footnotetext{
54 There is an argument to that effect in Phelps, Political Economy: An Introductory Text, Norton, 1985. See also theoretical modeling to this end in work by Joseph Stiglitz.
} 
create a channel through which the entrepreneur's wealth works in the opposite way to what was suggested earlier: The wealthier the entrepreneur, the harder it is for financiers to motivate him to make a highly stressful level of effort and to incentivize him not to engage in self-dealing. This incentive consideration, taken alone, operates to make entrepreneurial activity decrease with increased wealth in the hands of entrepreneurs. A similar effect from an adverse economic culture could result.

\section{Economic Performance: the Role of Innovative Activity}

Two propositions appear to be implicit in most recent commentary and certainly in this conference. First, a sort of triad of features - an abundance of new entrepreneurial ideas, entrepreneurs capable (often in partnership with financiers) of providing suitable development of their ideas, and a pluralism of financiers with a background sufficient to make a good selection of ideas and entrepreneurs for backing - is central to innovation and thus to high economic performance. Second, that shortcomings or barriers in some or all of these respects lie at the heart of the unsatisfactory performance characteristics that the western Continent's economies are widely inferred to have. I subscribe to both propositions. Yet we need to be clearer about what we mean by economic performance and why a country's economy must be structured for innovative activity - particularly innovation by indigenous innovators - to be a high-performance economy.

The extent of an economy's performance capabilities and the satisfactoriness of an economy's use of its capabilities are two quite separate concepts. A high-performance car may be used just to go down the street for groceries. Analogously, a high-performance economy may be largely devoted to some might say wasted on - the provision of social insurance and social assistance; an economy may be a very poor performer yet an exemplar of free-market principles, including the austerity of its entitlement programs, if any. The distinction is between choosing a bad point on the frontier and having a bad frontier of points to choose among.

The valuable capabilities that an economy may possess to one degree or another - the capabilities described by the economy's frontier - are several, of course. In advanced economies, a good prospect of surviving long enough to have a meaningful life is obtainable at such a small cost that we can skip over that and go to the capabilities that are more costly - capabilities without which survival might not be valued much. Of huge importance, I believe, is the economy's capability of providing people prospects of careers generating mental stimulation, intellectual challenge, problem-solving and maybe the exercise of creativity, thus prospects of personal development (self-realization) and various attainments (independence, recognition, and pride in earning one's way). This philosophy of life, by the way, is sometimes called vitalism, which runs from Aristotle to 
Cervantes to Wm. James and Henri Bergson. ${ }^{55}$ There are other capabilities, of course. The productivity with which labor and capital can produce is also an important capability even in an advanced economy. High productivity is to be preferred to lower productivity in part because increases in income have valuable uses but also because increases in the wage rate across the economy help workers to afford to opt for the more engaging and rewarding jobs. Another capability is the freedom and the means to find and take preferred employment opportunities, which translates into rights to enter, to be free of licenses and fees, to be permitted to hold property and accumulate wealth. Yet another capability is the degree of security from destitution, which involves the provision of private or social insurance arrangements. An increase in one capability would generally permit nationals through substitution to "take out" the gain in the form of enjoying more of every capability. But a capability might require some factor of production specific to that capability, so that the abundance of the other capabilities will not help in providing that capability.

A thesis of mine is that if an economy's capability in providing rewarding work is to go from some barely adequate level to a level out of which can come substantial personal development and attainment, the economy needs the dynamism to generate a sufficient flow of innovations. Further, a well-functioning capitalist system possesses the dynamism to generate adequate innovation: Capitalism's dynamism - the abundance of the entrepreneurial ideas it stimulates, the diligence with which entrepreneurs are motivated to develop their idea, and the acumen of a pluralism of financiers in selecting the ideas for backing - generates successive entrepreneurial ideas that serve to provide mental stimulation in the workplace, to pose new problems to be solved, and thus to open the way to self-realization and gratification. (Of course, not every job can be exciting and fascinating, but virtually all jobs are more engaging and challenging in relatively capitalist economies than in the others - from the Continent's corporatism to the earlier socialism of eastern Europe.)

The vitalist quality of the workplace in a country and even the innovativeness of the economy creating it, if they are present, cannot be easily observed and measured. But various statistics can be interpreted as signs of the quality of business life: the labor force participation rates of men and of women, the quit rate of employees and the unemployment rate, the length of the workweek and number of vacation days, and the level of hourly productivity (adjusted where needed for low-skill person excluded from employment). Some other indicators may constitute circumstantial evidence of engaging and rewarding work or the dearth of it: a high saving rate, a low retirement age, and a relationship between employees and employers that seldom breaks out into open conflict. In short,

\footnotetext{
55 "The Economic Performance of Nations: Prosperity Depends on Dynamism, Dynamism on Institutions," in Eytan Sheshinski, ed., The Growth Mechanism of Free Enterprise Economies, Princeton: Princeton University Press, forthcoming 2006.
} 
ample vitalist rewards and challenges in the workplace and thus the dynamism that fuels them leave markers that add up to a visible sense of prosperity or flourishing ${ }^{56}$

So my thesis leads me to interpret the data in western continental Europe preponderantly high unemployment rates, low labor force participation rates, short workweeks, and somewhat low productivity relative to the U.S. (and some other comparators, including Ireland, Australia, U.K. and Canada) - as evidence of relatively poor economic performance in a fundamental dimension: an insufficiency of stimulation, engagement and intellectual challenge in the workplace. And, in my thesis, this deficiency can in turn be laid to an insufficiency of innovation. The latter also affects performance in another dimension: relative productivity. This interpretation of the Continent's apparently unsatisfactory state requires defense, however.

Proponents of the supply-side interpretation argue that it is the "excess burdens" of the welfare system on the Continent that largely accounts for its relatively low employment and the dearth of enterprising spirit among potential innovators. They blame the Continent's increased unemployment and its failure fully to catch up on the ill-effects of the Continent's social model, which expanded enormously in the 1970s and 1980s, rather than on the economic model - the economic system (institutions and culture) in the terminology here. By the late 1980s Richard Layard and Stephen Nickell were contending that the increased unemployment rates were simply the result of huge replacement ratios that had come to be built into unemployment compensation programs. I myself showed in my 1994 book Structural Slumps that increases in the tax rate on labor, thus cuts in the after-tax real wage rate, had distributed-lag effects on the unemployment rate and in a 1997 paper found some evidence in U.S. times series for believing that the level of the welfare state might make a difference. ${ }^{57} 58$ But I subsequently noticed that some evidence brought up by Robert Mundell, in the form of a cross-section scatter diagram of the OECD economies, was pretty thin. A look at such data in 1998 and a further analysis in 2004 made me skeptical that the welfare state was the main culprit in the low employment on the Continent. ${ }^{58}$ So for some years I have attributed the Continent's poorly performing system far less to its social model than to its economic model. ${ }^{59}$ The near-stagnation striking several continental economies, one after the other, over the past ten years has only

\footnotetext{
56 This was the main theme in Phelps, "The Continent's High Unemployment: Possible Institutional Causes and Some Evidence." Keynote Paper at the Conference on Unemployment in Europe, CESifo and Yrjo Jahnsson Foundation, Munich, December 6-7, 2002. Conference volume, MIT Press, forthcoming 2006.

57 Edmund Phelps and Gylfi Zoega, "The Rise and Downward Trend of the Unemployment Rate in the U.S.," American Economic Review, May 1997.

58 Phelps and Zoega, 'Natural-rate theory and OECD unemployment,' Economic Journal May 1998 and "Searching for Routes to Better Economic Performance," Forum, CESifo, March 2004.

${ }^{59}$ This thesis was first stated and developed to some extent in Phelps, Enterprise and Inclusion in Italy, Kluwer, 2002 and broadened somewhat to include economic culture in a keynote speech, "The Continent's High Unemployment: Possible Institutional Causes and Some Evidence," Conference on Unemployment in Europe, CESifo, Munich, December 2002.
} 
strengthened my conviction.

Some opposing the dynamism thesis say that the Continent's economic performance is not inferior to that in the U.S. whether or not the Continent's dynamism is less. They deny that a wide comparison of economic performance would favor the U.S. and they suggest that if dynamism should be found relatively deficient on the Continent, that would only show that dynamism is not very important for high performance. They point to particular uses of the economy to which they are partial, such as extensive provisions for protection of the environment and for the economic security of the poor and the aged. They also point to high levels of saving and wealth. But the perceptions, such as mine, of relatively poor economic performance on the Continent are focused on non-pecuniary rewards from jobs, employment, wages and productivity. And there cannot be much doubt that the Continent as a whole is inferior on that score to the 50 states of the Union as a whole. ${ }^{60}$

Some other opponents of the dynamism thesis say that the Continent's dynamism is not inferior to that in the U.S. whether or not the Continent's economic performance is poorer. They deny that the evidence over the sweep of history points to a deficiency of dynamism on the Continent. They point to the era previous to the Continent's slump - the "glorious years" from the mid-1950s to the mid-1970s - when West Germany and France, later Italy and some of the smaller economies, experienced a great spurt in productivity and an accompanying surge of employment, dubbed the "economic miracle." But does that prove that the Continent's economic system is dynamic now - no less than the U.S. system? Or dynamic then?

In an opinion concurring with the dynamism thesis on its main point yet different from my formulation, the late Mancur Olson argued that the Continent was fairly dynamic then, thanks to the war, which wrested the economy from the paralyzing grip of entrenched monopolies and old wealth, and to such liberal reformers as Ludwig Erhard and Luigi Einaudi, who were favored over the postwar socialists and communists. In Olson's view, though, the Continent gradually lost its dynamism in ensuing decades as powerful unions and monopolies retook power. ${ }^{61} \mathrm{I}$ have to pass over his argument here.

\footnotetext{
60 Those with long memories might observe that over the century as a whole Continental unemployment was not worse than in the U.S. It is a fact that in the 1930s, when depression tendencies were worldwide, the Continent did a better job at combating unemployment than the U.S. did. But the poorer record of the U.S. in that respect was almost certainly not inherent in the nature of the contrasts between the Continental and the U.S. economic systems. The U.S. could have greatly moderated the rise of unemployment through a monetary policy that avoided a deep deflation early in the decade and refrained from industrial policies that must have had a chilling effect on entrepreneurs' spirits in the second half of the decade. Similarly, the Continent's better record on unemployment appears also to have owed much to its more vigorous public works rather than any immunity of its economic system to double-digit unemployment rates.

61 Mancur Olson, The Rise and Decline of Nations, New Haven: Yale University Press, 1983. I do not recall seeing any suggestion in his later writing that there was or might have been a rebirth of dynamism later on.
} 
I take the simpler position, of which Herbert Giersch was perhaps the leading forerunner. In my view, the Continental economies have never been dynamic - not since sometime in the 1920s. How then to reconcile the Continent's rapid productivity growth with a dearth of dynamism? I argue that in the Continent's glorious years the spurt of productivity and wages was fueled by the abundant stock of new methods and products overseas - mostly innovations made in the U.S.; once the war was over and the rails and bricks were put back together, the Continental economies with at least some amount of financial resources and some spread of university education could copy or adapt at little or no cost the U.S. goods and methods. Yet, as more and more of the low-hanging fruit was picked, the growth rate of Continental productivity was bound to slow more and more until it had sunk back to the growth rate in the U.S. . Moreover, the stock of private wealth, which had not kept up with wages when they were rising rapidly, grew to a normal level relative to wages once wages were again rising slowly, with the result that employees became more demanding and employer costs increased. Also, investing in training, marketing and plant had to be cut, with the result that many jobs were cut. Unemployment rates were forced up, leveling off only in the mid-1980s. Thus the Continental economies stood revealed as seriously lacking in dynamism after all. (They eked out some more productivity gains vis-à-vis the U.S. until the early 1990s, but the impression of a dearth of dynamism was largely confirmed.)

This explanation does not persuade all economists. Many remember the glorious years as full of Continental innovation - endogenous, thus Schumpeterian, and indigenous, not borrowed innovation from overseas. Some recall the innovators who grew famous in Italy and France in the 1950s and 1960s, such as Dior, Gucci, de Laurentis, Pinin Farina and a few others. It seems to these observers that the Continental system must have been "dynamic," otherwise these innovators would not have been on the stage; and if the institutions are much the same now, it is surely the case that the Continent still possesses dynamism: the premature halt to the productivity catch-up and the stubborn elevation of unemployment can only be the result of something else, such as a deterioration of economic prospects - demographic or technological. Yet this conventional impression is ripe for re-examination. First, it is striking that the great entrepreneurial figures just mentioned were nearly all confined to a handful of industries in what was a large and diversified economy, mainly design and cinema. And the successful innovations in the other industries during that period, like Chanel and Dassault, started up in the 1930s, so they do not bespeak of an Olsonian postwar dynamism. ${ }^{62}$

Another reply I would make refers again to wealth levels. The wavelet of innovation peculiar to the glorious years was the result of a dearth of wealth in the 1950 s and the 1960s relative to wages, which spurred many entrepreneurs to

${ }^{62}$ See David. Jestaz, "Reflexions sur le modèle français.” ms., Alliance Program, Columbia, July 2005. 
venture on new ways that might succeed in rebuilding their wealth, which a few managed to find. By the 1980s, when ample wealth-wage ratios were again widespread among Italians, Germans and the French, there were few entrepreneurial types hungry enough to want to battle the system for a place to try out their new idea; or they had come up with no idea, knowing how fruitless it would be to have a new commercial idea. In this argument of mine, more wealth meant fewer would-be entrepreneurs; that argument does not contradict the earlier hypothesis that more wealth also made each given entrepreneur more able to afford to make a concession to financiers in order to do the project he had set his sights on. Vastly more wealth across the population by the 1970s and 1980s meant that more young people entering university or the labor force aimed to be "entrepreneurs" in the political world, high society and the arts, where they would spend part of their wealth, not add appreciably to it by going into business. (In Thomas Mann's Buddenbrooks, if I remember correctly, those inheriting a fortune from their father did not have the same drive nor the same gifts for business that their father had and went into other pursuits; and the grandchildren went still farther afield.) Although the managerial positions were undiminished and had to be filled somehow, often by reaching down to a lower economic or social status, the number of entrepreneurial positions simply shrank. Perhaps the influx into the United States of immigrants who, with wealth levels generally far below the national average, were eager to replenish the stock of entrepreneurs has given this country a huge advantage over the Continental nations, whose borders have been almost closed until relatively recently.

Let me sum up my interpretation of the bearing of the Continental experience on the connection of performance, particularly the more vitalist elements of performance, to economic dynamism: The slowdown that developed on the Continent in the late 1970s was widely thought to be the initial descent toward a soft landing onto some path that be might be equivalent or superior to the path on which the more capitalist economies were following. But it was beginning to be apparent by the late 1980s that the Continent's future was to run a steady second place behind the innovative pace setter - its workplace duller than the American, hence its labor force participation lower and unemployment higher, and its productivity level a respectful distance behind the U.S. level. As it turned out, the Continent's catch-up with the U.S. in productivity terms came to an abrupt halt in the early 1990s, when U.S. productivity growth picked up - leaving hourly productivity noticeably lower than in the U.S. In the mid-1990s, unemployment rates were also generally higher on the Continent and labor force participation rates generally lower than in the U.S. and the U.K.

It should not have been puzzling that this performance was lackluster. The relative performance of France, Germany and Italy in the previous normal period the 1920s - was worse. Even in the abnormal period of the 1930s, the growth rate productivity in the U.S. continued its record-setting pace, which the Continental economies were unable to match. Evidently the "high years" of Continental 
innovations that stretched into the first decade of the $20^{\text {th }}$ century could not survive the changes to the economic system that came into place in the Interwar period and were largely retained and further articulated after World War II. Between one century and the next there was a system shift.

Since the mid-1990s, an economic decline of sorts has set in as growth rates of hourly productivity dropped far below the U.S. rates: first the Netherlands in 1996, then Germany in 1998, next Spain in 1999 and then France and Italy in 2001. Unemployment rates, which had fallen for a time in the 1990s, are generally up again (Italy and Spain excepted) in 2005 and higher than in 1995, while in the U.S. the reverse has happened. The premature end of the catch-up turned into a serious falling-back, which has still not come to a halt.

The question is, then, what are the main sources of the poor performance characteristics and thus the relatively poor dynamism found in most if not all the Continental economies - compared to the U.S. and possibly other comparators?

What I have come to in the past couple of years is a speculative hypothesis that, while still speculative, is more refined view than I held until a few years ago: ${ }^{63}$ It is very difficult to find a unique "smoking gun" in the form of some particularly deadly economic institution or subset of economic institutions - in corporate governance, in finance, in regulation and so forth - that could account for the relative dearth of dynamism on the Continent. Research aimed at weighing the total influence of those institutions must go on and I will be active in contributing to that. Yet we must widen our net.

It is necessary, I believe, to give more weight to economic culture than I was prepared to do in previous years as recently as 2002 and 2003. The explanation modified thesis is that the Continent (and to some extent the U.K. too) is in the grip of a culture hostile to enterprise and innovation. But I will leave the development of these thoughts for another occasion.

\section{Concluding Remarks}

The ongoing research I have discussed is aimed at modeling capitalism along the modern (or modernist) lines proposed at various times by Knight, Keynes, Hayek and M. Polanyi - and inevitably Schumpeter, though many of his concepts remained unnaturally classical. In the modern theory, business participants hit upon new commercial ideas inspired in large part by their specialized knowledge and idiosyncratic experience. Those interested in becoming entrepreneurs implementing their idea must first invest the time required to prepare a case for presentation to potential financiers. At the innovation market, or "fair," the entrepreneurs supplied to the market compete for an experienced financier to provide financing and advice on their project and the financiers try to match up

\footnotetext{
${ }^{63}$ I focused on economic institutions in the previous decade. See my Enterprise and Inclusion in Italy, Kluwer, 2002
} 
with a likeminded entrepreneur through interviews and the offer of a contract. A match between entrepreneur and financier permits them to develop the entrepreneur's new idea. If that development is successful, the innovation is launched and marketed in an attempt to win early acceptance and rapid spread of the new product or service or organization among potential users, either producers or consumers. An unsuccessful innovation is one that is shelved owing to insufficient prospects for demand, although the idea and its development will perhaps be retained for a time by some in the economy. A successful innovation is one that finds a demand among users sufficient to warrant putting the innovation into regular production. Through time, understanding of the attractions of the innovation may diffuse through the market, causing the demand to widen. Such an innovation may ultimately earn a pure profit, also known as an economic profit, or instead a pure loss, or economic loss.

Thus capitalism is seen as a system for producing and using new ideas, and these ideas could in principle be represented as new models of the economy (or a piece of it). Some new models succeed in establishing themselves at least for a time while others fail. The innovation process thus produces an accumulation of models, which we could imagine reaching some steady-state level though the current extant models have the property that they have driven out previous models. One of the obstacles to a "model" of the capitalist system has been the difficulty of conceiving how financiers are able and willing to back entrepreneurial projects when, as is generally the case, these financiers can have little idea of what the true prospects of profitability are. In section 2 of this paper I provided a sketch of a model that offers a way out of that problem - whether or not it is the only way or the best way.

There is the strong possibility that the current assortment of models being applied in the production sector is preferable to the previous assortment, given existing tastes and scientific knowledge. However, for active-age people in economically advanced countries it is the process - the stimulation, problem solving and personal development that comes out of the creation, development, marketing, pioneering use and learning experienced by those who are engaged in the production and use of the innovation - that may provide the greater part of the benefit to the economy's participants. So the dynamism generated by the innovation process does not have to produce faster growth than produced by all fundamentally different systems for the innovations of a capitalist, thus an entrepreneurial economy to be essential for rewarding careers. 


\section{Bibliography}

'Europe's stony grounds for the seeds of growth,' Financial Times, August 9, 2000.

Full version in electronic form at Phelps's website (columbia/edu esp2).

'Structural booms,' with Gylfi Zoega, Economic Policy, April 2001.

Enterprise and Inclusion in Italy, Dordrecht, Kluwer, 2002.

"The Continent's High Unemployment: Possible Institutional Causes and Some Evidence," Keynote Lecture, Conference on Unemployment in Europe, CESifo, Munich, 1-2 December 2002. Published in Martin Werding, (ed.), Structural Unemployment in Western Europe: Reasons and Remedies, Cambridge, Mass.: MIT Press, 2006, 53-74.

"The Economic Performance of Nations: Prosperity Depends on Dynamism,

Dynamism on Institutions." Conference on Entrepreneurship, Innovation and the Growth Mechanism of the Free-Market Economies, Nov. 2003. In Eytan Sheshinski, ed., The Growth Mechanism of Free Enterprise Economies, Princeton: Princeton University Press, forthcoming 2006.

"French and Continental Influences on Modern-Day Political Economy," Speech on the Occasion of an Honorary Doctorate, University of Paris-Dauphine, June 2, 2004.

"Entrepreneurship and Innovation in Capitalist Systems," for the Kauffman Thoughtbook 2005, November 11, 2004.

"What Distinguishes a Prospering and Developing Economy? What Kind of Institutions Does It Require?” Lecture, ICRIER, New Dehli, 30 December 2004

American Cowboy Capitalism vs. Euroscelerosis, Debate at CUNY, Sponsored by the Smith Family Foundation, with Jeff Madrick, New York, March 8, 2005.

Television broadcast CUNY March 16, 2005.

What Alternatives to American Capitalism? Debate at the University of ParisSorbonne, with Christian de Boisseux, Paris, March 15, 2005.

"The Importance of Capitalism and its Institutions in any Structural Reform of the Continental Economies," OFCE seminar, Paris, March 17, 2005 (OF CEseminarMarch05rev3).

"Changing Prospects, Speculative Swings: Modeling Where Rational Expectations Does Not Apply," forthcoming, Michael Szenberg, ed., Festschrift volume in Honor of Paul A. Samuelson on his $90^{\text {th }}$ Birthday, May 15, 2005.

"A Theory of China's Course: the Role of Knowledge in Selecting and Adapting Overseas Innovations and in their Diffusion in the Home Market," Nobel Laureates Beijing Forum 2005. The Great Hall of the People, Beijing, May 31, 2005.

"Recollections of my Past Research in Economics," Speech on the Occasion of an Honorary Professorship, Beijing Technology and Business University, Beijing, June 1, 2005. 
"Business Cycles and the World Economy," Nobel Laureates Forum 2005, Chinese University of Hong Kong, June 3, 2005.

"Channels and Mechanisms Linking Future Budgetary Shocks to Present Asset Prices and Economic Activity," with H. T. Hoon, $2^{\text {nd }}$ Annual Conference, Center on Capitalism and Society, Reykjavik, 16-17 June 2005

"Can Capitalism Survive?" After-Dinner Speech at the Home of President Olaf Grimsson, Reykjavik, June 17, 2005. Trans., Icelandic, Bulletin of the Central Bank of Iceland, Winter 2006.

"China's Growth Mechanism and Some Overlooked Impacts on the Rest of the World," paper given at the Festschrift for Prof. Juergen Schroeder, Eltville-am- Rhein, June 19, 2005 .

"What are the Sources of the Greater Dynamism in the More Capitalist Economies?: A Consideration of their Financing," Villa Mondragone International Seminar, Frascati (Rome), July 6-7, 2005.

“About economic vitalism," L 'Europe et les Etats-Unis: au-delà des idées convenues, Paris, Descartes \& Cie, 2006. Panel Discussion of Le Cercle des economistes, with Alain Juppe, Pascal Lamy and Mario Monti, Aix-en-Province, 8 July 2005.

“A Dynamic Theory of the China-U.S. Trade: Making Sense of the Imbalances," with Amar Bhide, Working Paper no. 4, Center on Capitalism and Society, July 2005.

"Classical Theory vs. the Real World," with Amar Bhide, Wall Street Journal, July 25, 2005.

"Understanding the Great Changes in the World: Gaining Ground and Losing Ground since World War II," Lecture, International Economic Association World Congress, Marrakech, August 28-September 2, 2005. Revised Sept. 30. 31pp + Appendix.

"Entrepreneurship and Innovation in Capitalist Systems," Understanding Entrepreunership, Kauffman Foundation: Kansas City, 2005, 26-30.

"Further Steps to a Theory of Innovation and Growth - on a Path Begun by Knight, Hayek and Polanyi," Annual Meeting of the American Economic Association, January 7, 2006.

"Effects of Technological Improvements in the ICT-Producing Sector on Business Activity," with Hian-Teck Hoon, Singapore Management University, February 2006. (Posted on the CU Econ. Dept. website.) Submitted to American Economic Review. 